\title{
Keterlibatan Amerika Serikatdalam Sengketa Laut Tiongkok Selatan pada Masa Pemerintahan Presiden Barack Obama
}

\section{Arief Bakhtiar Darmawan}

International Relations DepartmentUniversitas Jenderal Soedirman JI. HR Boenyamin 993, Purwokerto Utara, Jawa Tengah 53122, Indonesiaarief.darmawan@unsoed.ac.id

\section{Gebyar Lintang Ndadari}

International Relations DepartmentUniversitas Gadjah MadaSubmitted: 04 August 2017,

Accepted: 27 September 2017

\begin{abstract}
This article aims to analyze the United States (U.S.) involvement in the South China Sea (SCS) dispute. It argues that U.S. involvement has strong reasons and gives significant impact on the region. Jurisdictional claims in the SCS amongst claimants have increased the military activities in the region. Therefore, U.S. needs to increase its presence and involvement in the dispute area. These actions are intended to maintain U.S. interests in the region and secure its national security in the SCS, especially to preserve American global leadership and to maintain peace and stability. Using the concept of balance of power and national security, this article explains that U.S. involvement causes the status quo in the SCS. Although the U.S. is working closely with the Philippines and Vietnam to be a balance of power in the region, U.S. involvement does not use the military power or conflict against China in the SCS.

Keywords: United States involvement, the South China Sea dispute, balance of power, national security, The Philippines, Vietnam.
\end{abstract}

\begin{abstract}
Abstrak
Artikel ini bertujuan untuk menganalisis keterlibatan Amerika Serikat (AS) dalam sengketa Laut Tiongkok Selatan (LTS). Artikel ini berargumen bahwa keterlibatan AS tersebut memiliki alasan yang kuat dan memberi pengaruh yang signifikan atas situasi yang terjadi di kawasan tersebut. Klaim tumpang-tindih enam pihak atau negara atas wilayah LTS telah meningkatkan ketegangan di kawasan. Hal itu membuat AS memperkuat kehadiran dan keterlibatannya di kawasan tersebut. Keterlibatan AS merupakan bagian dari upaya AS untuk memelihara keamanan dan kepentingan nasional atas LTS, serta menjaga kepemimpinan global, perdamaian, dan stabilitas di kawasan. Dengan menggunakan konsep perimbangan kekuatan dan keamanan nasional, artikel ini menunjukkan bahwa keterlibatan AS menyebabkan status quo atas apa yang terjadi dalam wilayah LTS. Meskipun AS bekerja sama dengan Filipina dan Vietnam untuk menjadi kekuatan penyeimbang kekuatan di kawasan, namun keterlibatan AS tidak sampai pada penggunaan kekuatan militer atau konflik terbuka melawan Tiongkok di LTS. Kata kunci: keterlibatan AS, sengketa Laut Tiongkok Selatan, perimbangan kekuatan, keamanan nasional, Filipina, Vietnam.
\end{abstract}

\section{PENDAHULUAN}

Kebijakan luar negeri Amerika Serikat (AS) untuk terlibat baik langsung maupun tidak langsung dalam sengketa Laut Tiongkok Selatan (LTS) menjadi fokus utama dalam tulisan ini. Mengapa topik tersebut penting untuk dibahas lebih lanjut? Selain karena sifat isu sengketa LTS yang penuh benturan kepentingan dan berpotensi

mengganggu stabilitas kawasan, keterlibatan AS juga menarik karena AS bukan merupakan pihak yang bersengketa langsung dalam klaim wilayah di LTS. Pergeseran kebijakan AS menjadi 'high-profile intervention' di kawasan Asia-Pasifik lebih memiliki kaitan dengan keamanan nasional yang harus dilindungi, baik dalam 
wilayah yang disengketakan maupun pada negara-negara di kawasan tersebut (Haryanto \& Bakhtiar, 2015: 278).

AS menyatakan bahwa kehadirannya dalam sengketa LTS hanya dalam upaya untuk menjaga kebebasan navigasi kapal di perairan internasional, menjaga perdamaian dan mengurangi risiko sengketa di kawasan, serta tidak mendukung pihak mana pun dalam sengketa. Namun demikian, upaya tersebut juga diikuti dengan berbagai aktivitas kerja sama militer di wilayah sengketa. Aktivitas tersebut dapat dilihat, misalnya, melalui kunjungan Menteri Luar Negeri AS Hillary Clinton ke Filipina pada tahun 2011 untuk menekankan kembali kerja sama militer kedua negara. Clinton menyatakan bahwa kerja sama kedua negara menjadi dasar dari hubungan bilateral, penguatan visi bersama mengenai kerja sama strategis, politik, ekonomi, dan hubungan people-to-people (VOA, 2011). AS juga menjalin kerja sama militer dengan Vietnam. Kerja sama militer antara kedua negara dimulai sejak 1 Agustus 2010, dengan ditandatanganinya Statement of Intent on Military Medical Cooperation di Hanoi (China Daily, 2011). Kerja sama ini merupakan hubungan kerja sama militer pertama secara formal setelah berakhirnya perang antara kedua negara tahun 1975. Hubungan kerja sama tersebut terus mengalami peningkatan, terutama terlihat pada kunjungan Menteri Pertahanan AS Leon Panetta bersama dengan masuknya kapal perang AS ke Teluk Cam Ranh pada Juni 2012. Kunjungan Panetta menjadi kunjungan pertama pejabat tinggi dari AS sejak terjadinya Perang Vietnam (Weisgerber, 2012). Selain melalui aktivitas militer, bentuk kehadiran lain dari AS di wilayah sengketa berupa kegiatan eksplorasi sumber daya. Tahun 2011, misalnya, perusahaan ExxonMobil AS mulai melakukan survei pengeboran minyak di blok 119 yang dijalankan oleh perusahaan nasional Vietnam. Sebagian wilayah perairan tersebut diklaim pula oleh Tiongkok (Kate, 2011).

Dalam tulisannya yang berjudul America's Pacific Century, Hillary Clinton (2011) menyatakan bahwa 'harnessing Asia's growth and dynamism is central to American economic and strategic interests and a key priority for President Obama.' Selain itu, Hillary menegaskan bahwa AS harus menempatkan diri dalam posisi 'at the center of action' untuk melanjutkan kepemimpinan, mengamankan kepentingan, dan meningkatkan nilai-nilai AS di Asia. Keyakinan Hillary diperkuat dengan pernyataan Presiden Obama pada Januari 2012 untuk mengurangi kehadiran militer AS di Eropa, Irak, dan Afghanistan berupa pengurangan separuh jumlah pasukan militer, serta pengalihan fokus ke AsiaPasifik (The New York Times, 2012). Dengan pernyataanpernyataan ini, tampak bahwa keterlibatan AS dalam sengketa LTS menunjukkan kepentingan besar AS di wilayah sengketa.

Dengan latar belakang tersebut, pertanyaan yang berusaha dijawab tulisan ini adalah mengapa AS bekerja sama dengan Filipina dan Vietnam dalam konteks keterlibatannya dalam masalah sengketa di LTS dan bagaimana strategi kerja sama AS dengan Filipina dan Vietnam itu dijalankan. Dalam tulisan ini, penulis mengajukan hipotesis bahwa AS ikut terlibat dalam sengketa LTS, khususnya bekerja sama dengan Vietnam dan Filipina karena ingin melakukan perimbangan kekuatan terhadap Tiongkok. Strategi AS untuk melakukan perimbangan kekuatan terhadap Tiongkok dilakukan melalui bentuk kerja sama peningkatan kekuatan militer dengan Filipina dan Vietnam. Dengan menganalisis kepentingan AS terhadap keamanan nasionalnya, penulis juga berargumen bahwa intervensi AS di kawasan LTS menyebabkan adanya deterrence dan menghasilkan situasi status quo, di mana intervensi ini tidak berujung pada konflik yang melibatkan kekuatan militer dua negara besar, yaitu AS dan Tiongkok.

\section{PEMBAHASAN}

PERIMBANGAN KEKUATAN DAN KEAMANAN NASIONAL SEBAGAI LANDASAN KONSEPTUAL

\section{Perimbangan Kekuatan (Balance of Power)}

Hans Morgenthau berpendapat bahwa politik internasional dapat diartikan sebagai sebuah perjuangan demi kekuasaan negara dan pemenuhan kepentingan nasional. Hal ini menurutnya merupakan suatu aktivitas yang normal dan tidak dapat dihindari (Morgenthau, 1991: 4). Negara-negara bisa terlibat dalam konflik karena masingmasing mengejar kepentingannya sendiri. Di sinilah perimbangan kekuatan menjadi penting. Sistem perimbangan kekuatan oleh karenanya dapat dipahami sebagai faktor utama untuk menjaga stabilitas dalam hubungan internasional. Perimbangan kekuatan 
digunakan untuk mengatur kecenderungan negara-negara dalam menghimpun kekuatan secara strategis. Konsep perimbangan kekuatan dinyatakan sebagai suatu keadaan nyata di mana kekuasaan terbagi secara kurang lebih sama di antara beberapa negara (Morgenthau, 1991: 57).

Charles Kegley dan Eugene Wittkopf menyebutkan bahwa perimbangan kekuatan adalah 'a measure of the amount of military power states or blocs hold in relation to each other' (Kegley \& Wittkopf, 2001: 347). Oleh karena itu, konsep perimbangan kekuatan lekat dengan perhitungan kekuatan militer antarnegara. Konsep perimbangan kekuatan yang secara umum memperlihatkan tradisi klasik dari kaum realis ini menekankan pada asas kesetaraan (ekuilibrium) antara negara-negara besar dalam suatu kawasan. Realis memandang bahwa penyebaran merata kekuatan militer adalah hal yang baik, karena dengan kekuatan yang seimbang maka perdamaian akan cenderung terjadi. Perimbangan kekuatan mengajarkan bahwa setiap negara harus meningkatkan kapasitas dan kemampuan militernya untuk melakukan perlindungan terhadap dirinya sendiri. Dalam upaya untuk mencapai kepentingan nasional, terutama perluasan pengaruh, negara-negara besar cenderung menggunakan isu-isu yang berkaitan dengan perimbangan kekuasaan. Oleh karena itu, persepsi negara besar mengenai suatu penguasa (hegemon) dalam satu kawasan dianggap akan sangat berpengaruh terhadap kebijakan negara tersebut terhadap berbagai kawasan lain (Ayoob, 1999: 252). AS dapat dikatakan sebagai penyeimbang (balancer) di wilayah LTS. Tugas sebagai penyeimbang biasanya diberikan kepada satu negara dengan kekuatan besar yang bertujuan untuk menjaga kesetimbangan distribusi kekuatan (Wegley \& Wittkopf, 2001: 556).

Dalam perkembangannya, bentuk perimbangan kekuatan dapat diwujudkan dengan campur tangan negara luar dalam suatu wilayah maupun kawasan dalam bentuk kerja sama bilateral maupun multilateral. Dengan kerja sama, diharapkan akan terdapat kesamaan pola pikir, nilai, tujuan, dan tindakan yang dilakukan untuk mencapai tujuan (Morgenthau, 1991: 178). Selain itu, diharapkan pula akan terdapat satu komitmen dan loyalitas dari negara-negara kawasan untuk mengikuti tindakan politik dari negara luar tersebut. Dengan bergabungnya negara-negara dalam satu kerja sama tertentu, asumsi yang kemudian muncul ialah mereka akan mendapatkan berbagai keuntungan, terutama dalam penambahan kekuatan militer. Negara dari luar kawasan membangun kontrol atas wilayah dan memiliki tujuan tertentu untuk mendapatkan keuntungan demi kepentingan nasionalnya secara maksimal. Kekuatan eksternal yang berusaha membentuk suatu struktur kerja sama dalam wilayah tertentu menggunakan cara yang sejalan dengan kepentingan negara-negara di kawasan, baik untuk menghambat pengaruh dari apa yang disebut negara luar itu sebagai lawan atau saingan, maupun untuk membangun kontrol dan pengaruh atas wilayah tersebut. Situasi ini dikategorikan oleh Barry Buzan dan Ole Wæver sebagai overlay (Buzan \& Wæver, 2006: 61).

Buzan menekankan bahwa aktor eksternal dapat mengubah struktur kekuatan lokal dan regional dengan dua cara, baik dengan cara bergabung dalam struktur itu atau dengan membuat keberpihakan di dalamnya. Dengan demikian, overlay dapat menjelaskan mengenai aktivitas dari negara-negara besar dalam suatu wilayah atau kawasan, dalam konteks ini terutama berkaitan dengan aktivitas AS di wilayah LTS. Kerja sama militer AS dengan Vietnam dan Filipina memperlihatkan keinginannya untuk menciptakan overlay.

\section{Keamanan Nasional}

Seperti halnya perimbangan kekuatan, konsep keamanan nasional masih lekat dengan asumsi realis. Meskipun definisi keamanan masih belum dapat disepakati secara jelas, namun secara tradisional, keamanan berkaitan dengan fungsi dari keberhasilan kompetisi negara-negara dalam meraih kepentingan masing-masing. Dalam konteks ini, keamanan nasional didefinisikan sebagai kapasitas suatu negara untuk menangkal ancaman dari luar maupun dalam negeri melalui ketahanan secara fisik (militer) maupun dengan nilai-nilai utama negara tersebut (Kegley \& Wittkopf, 2001: 556). Lebih jauh, keamanan nasional berkaitan dengan pemikiran psikologis mengenai kebebasan negara dari ancaman-ancaman yang diyakininya. AS memposisikan dirinya 'at the center of action', dengan pemikiran bahwa sengketa LTS dan peningkatan aktivitas militer Tiongkok merupakan ancaman bagi keamanan nasionalnya. Kehadiran AS menuju pusat ancaman juga 
menjadi satu upaya negara ini mempertahankan dominasi pengaruhnya.

Dalam pandangan Joseph Nye, politik internasional di era kontemporer saat ini bersifat self-help system. Hal tersebut berkaitan dengan ketiadaan kedaulatan global (common sovereign) karena negara berfokus pada kedaulatan secara individual. Hal ini terjadi karena pada dasarnya tidak terdapat institusi yang memiliki otoritas lebih tinggi daripada negara. Ketiadaan otoritas untuk menciptakan atau memaksa keteraturan (order) di level internasional merupakan implikasi dari sistem self-help yang lebih menekankan pada kemampuan negara untuk bertahan hidup (Nye, 2005: 20). Oleh karena itu, dapat dipahami bahwa negara-negara yang bersengketa di LTS mengupayakan berbagai cara, seperti peningkatan militer dengan bantuan negara besar, untuk membantu meningkatkan kemampuan bertahan mereka. Vietnam dan Filipina melakukan hal itu melalui kerja sama militer mereka dengan AS.

Saat menjadi salah satu kandidat presiden AS, John F. Kennedy pernah mengatakan 'it is an unfortunate fact that we can only secure peace by preparing for war' (Kegley \& Wittkopf, 2001: 456). Pernyataan Kennedy ini menunjukkan bahwa kemampuan militer memang sangat dibutuhkan untuk meningkatkan keamanan nasional suatu negara. Kaum realis percaya bahwa kemampuan untuk melakukan tindakan koersi merupakan kebutuhan utama. Pandangan ini kemudian dikembangkan dengan anggapan bahwa tidak hanya kemampuan secara militer saja yang dibutuhkan untuk meningkatkan keamanan nasional negara, namun juga peningkatan dalam kemampuan ekonomi. Masing-masing negara yang bersengketa di LTS membutuhkan peningkatan keamanan nasional untuk menangkal ancaman yang muncul.

\section{BENTUK KETERLIBATAN AMERIIKA SERIKAT DALAM SENGKETA LTS}

Sengketa LTS berkaitan dengan empat negara di Asia Tenggara, yaitu Vietnam, Filipina, Malaysia, dan Brunei Darussalam. Oleh karena itu, keterlibatan AS dalam arena sengketa tidak lepas dari sejarah kehadiran AS di kawasan Asia Tenggara yang pasca-11 September menjadi fokus kebijakan luar negeri AS mengenai terorisme. ${ }^{1}$ Keterlibatan AS mengambil empat bentuk utama, yaitu pergeseran pasukan militer ke Asia-Pasifik, tuntutan terhadap ASEAN, serta kerja sama dengan Filipina dan Vietnam.

\section{Pergeseran Pasukan Militer ke Asia-Pasifik}

Dengan fokus politik AS yang berubah ke kawasan AsiaPasifik, hubungan AS yang lebih erat dengan negara-negara di kawasan tersebut juga mulai dikembangkan. Kebijakan Obama untuk mengalihkan fokus militer dan politik luar negerinya ke Asia Pasifik berimplikasi pada perubahan strategi militer AS. Diawali dengan pernyataan Obama di Pentagon mengenai pemotongan anggaran militer, kebijakan tersebut ditunjukkan dengan penarikan militer AS dari wilayah-wilayah Timur Tengah dan Eropa. Menurut pernyataan Obama, di tahun 1999 jumlah tentara AS di Irak dan Afghanistan berjumlah 180.000 orang, pada tahun 2012 jumlah tersebut telah berkurang menjadi setengahnya dan akan terus berkurang (The New York Times, 2012). Di Eropa, AS menarik dua brigade pasukan tempur Angkatan Darat yang terdiri atas 7.000 tentara dan akan digantikan oleh penempatan pasukan temporer yang akan dirotasi setiap beberapa waktu. Jumlah total pasukan yang berada di Eropa ialah 81.000 orang dan membawa keluarga berjumlah 100.000 orang. Dengan penempatan yang bersifat temporer, maka para prajurit tidak perlu membawa keluarga mereka dan akan menghemat anggaran militer AS. Hal tersebut juga diterapkan bagi kawasan Afrika dan Amerika Latin (Kompas, 2012).

Pemangkasan anggaran pertahanan berkaitan erat dengan kondisi ekonomi AS yang masih belum pulih akibat resesi. Dalam pidatonya, Obama menyatakan bahwa Budget Control Act telah disetujui Kongres pada tahun 2011 dan berujung pada pengurangan anggaran federal, termasuk anggaran pertahanan (The New York Times, 2012). Pemangkasan anggaran pertahanan berjumlah sebesar $\$ 487$ miliar dalam sepuluh tahun mendatang terhitung sejak tahun 2012. Oleh sebab itu, Departemen Pertahanan AS mengeluarkan satu strategi baru yang dituangkan dalam pedoman pertahanan pada awal tahun 2012, berjudul Sustaining U.S. Global Leadership: Priorities for $21^{\text {st }}$ Century Defense. Dalam dokumen sepanjang delapan halaman tersebut, secara jelas dituliskan bahwa AS memang memiliki kepentingan ekonomi dan militer secara khusus di kawasan Asia-Pasifik: 
'U.S. economic and security interests are inextricably linked to developments in the arc extending from the Western Pacific and East Asia into the Indian Ocean region and South Asia, creating a mix of evolving challenges and opportunities' (U.S. Department of Defense, 2012: 2).

Berdasarkan pernyataan Leon Panetta, salah satu strategi itu akan diwujudkan melalui reposisi Angkatan Laut dengan mayoritas kapal perang akan berada di Asia-Pasifik pada tahun 2020, yaitu sebesar $60 \%$ dari total kapal perang yang dimiliki AS, dibandingkan tahun 2012 yang telah berjumlah sekitar 50\%. Angkatan Laut AS juga telah merencanakan untuk menempatkan kapal tempur pantai jenis littoral combat ships (LCS) di fasilitas Angkatan Laut Singapura pada tahun 2025. Hal tersebut disampaikan dalam tulisan Panglima Operasi Angkatan Laut AS Laksamana Jonathan Greenert dalam majalah Proceeding terbitan U.S. Naval Institute. Menurut Greenert, alasan utama kegiatan-kegiatan kerja sama militer AS dengan angkatan laut negara-negara lain ialah bahwa AS membutuhkan pendekatan baru untuk tetap menjadi yang terdepan di seluruh dunia dengan meningkatnya kepedulian negaranegara mengenai kebebasan navigasi. Dengan keterbatasan anggaran tersebut, armada laut Amerika Serikat di tahun 2025 akan lebih mengandalkan kerja sama dengan pelabuhan dan fasilitas negara lain, di mana kapal-kapal, pesawat, dan para pekerja dapat mengisi bahan bakar, beristirahat, memasok, dan melakukan perbaikan ketika aktivitas militer dilakukan. Greenert menyatakan bahwa semua ini akan dapat membantu Angkatan Laut AS untuk melanjutkan global forward posture dengan jumlah kapal dan pesawat yang lebih kecil dari saat ini (Greenert, 2012).

\section{Tuntutan Kebijakan Luar Negeri AS terhadap ASEAN}

Dalam kasus LTS, keterlibatan pihak eksternal, terutama AS, dalam sengketa merupakan salah satu hal penting yang menjadi sorotan internasional. Keterlibatan AS telah dimulai sejak pertengahan tahun 1990-an. AS pertama kali mengartikulasikan kebijakannya di LTS saat terjadi ketegangan akibat okupasi yang dilakukan Tiongkok pada Mischief Reef pada akhir tahun 1994. Pada Mei 1995, juru bicara Departemen Luar Negeri Amerika Serikat menggarisbawahi lima poin penting mengenai kebijakan
AS di LTS (U.S. Department of State, 1995). Kelima poin itu adalah: (1) penyelesaian sengketa secara damai; (2) menjaga perdamaian dan kestabilan kawasan; (3) menjaga kebebasan bernavigasi; (4) netralitas dalam sengketa; dan (5) menghargai prinsip-prinsip internasional dalam UNCLOS yang telah ditetapkan pada tahun 1982 (Fravel, 2012).

Kelima poin penting di atas merupakan hal mendasar yang masih relevan bagi kebijakan AS di LTS hingga saat ini. Hal itu terlihat dengan masih digunakannya poin-poin tersebut dalam berbagai pernyataan pejabat senior pemerintahan mengenai isu LTS sejak tahun 2009. Di tahun 2010, AS mulai memperbarui kebijakannya di LTS dengan menambahkan tiga poin baru setelah adanya peningkatan ketegangan antara negara-negara pengklaim, terutama merespon permintaan khusus Vietnam di tahun tersebut untuk meminta bantuan negara-negara lain dalam penyelesaian sengketa (BBC News, 2012). Kebijakan tambahan AS tersebut dinyatakan dalam pertemuan tahunan ASEAN Regional Forum (ARF) di Hanoi. Dalam pertemuan tersebut, Menteri Luar Negeri Hillary Clinton menyampaikan poin-poin utama seperti yang telah disampaikan pada tahun 1995 plus ketiga poin baru. Pertama, mengenai dukungan AS dalam proses diplomatik secara kolaboratif oleh semua negara pengklaim tanpa kekerasan. Kedua, AS meyakini bahwa klaim wilayah laut yang sah harus berdasar pada pengukuran daratan dan hukum yang berlaku; hal ini ditunjukkan oleh upaya Amerika Serikat untuk meratifikasi UNCLOS. Ketiga, AS berkeinginan untuk memfasilitasi confidence building measures sesuai dengan Declaration on a Code of Conduct tahun 2002 serta mendukung penyusunan draf lengkap tata berperilaku (code of conduct) di LTS (U.S Departement of State, 2010).

\section{Kerja Sama AS-Filipina}

AS juga terlibat dalam sengketa LTS dalam bentuk kerja sama militer dengan Filipina. Di bawah Mutual Defense Treaty tahun 1951, AS menjadikan Filipina sebagai sekutunya. Filipina merupakan negara yang bergantung pada AS, terutama dalam keamanan eksternalnya. Kedua negara telah lama melakukan aktivitas militer bersama untuk meningkatkan kesiapan dan kemampuan militer 
Filipina dalam merespon ancaman keamanan serta menjaga kemampuan angkatan bersenjata Filipina (AFP) maupun militer AS. AS mendesain Filipina sebagai sekutu utama non-NATO pada 6 Oktober 2003 untuk mendukung invasi AS di Irak dan memerangi terorisme di Asia Tenggara (Lum, 2012: 14). Tahun 2011 menjadi tahun pertama diadakannya dialog strategis secara bilateral yang diadakan pada bulan Januari. Kurt Campbell, Asisten Menteri Luar Negeri AS untuk Urusan Asia Timur dan Pasifik, meyakinkan Filipina dengan menjanjikan penjualan peralatan pertahanan, pelatihan penjagaan pantai, dan angkatan laut, serta menyediakan konsultasi yang lebih dalam mengenai isu strategis, politik, dan militer (Castro, 2012: 1). Setelah Hillary Clinton menegaskan kembali hubungan militer antara AS dan Filipina pada tahun 2011, kerja sama militer terutama dalam segi maritim antara kedua negara semakin dipererat. Hal tersebut juga merupakan respon dari Presiden Benigno Aquino III atas terjadinya penyerangan kapal eksplorasi minyak dan kapal nelayan Filipina oleh kapal perang Tiongkok. Dengan pemicu tersebut, Presiden Aquino menyatakan keinginannya untuk meningkatkan anggaran militer dan menyambut peningkatan kerja sama militer dengan AS. ${ }^{2}$

Kerja sama militer Balikatan merupakan kegiatan latihan militer tahunan yang paling komprehensif di antara kerja sama lain antara AS dan Filipina. Diadakan pertama kali pada tahun 1991, Balikatan rutin diadakan hingga saat ini meskipun sempat mengalami penangguhan pada tahun-tahun 1995-1999. Tahun 2010 dan 2011, latihan militer bersama tersebut melibatkan kurang lebih 2.000 tentara AFP dan 6.000 tentara AS dengan aktivitas di antaranya pelatihan penyerangan, evakuasi dan penyelamatan, menjinakkan dan menghancurkan bom, latihan keamanan maritim, dan penanganan bencana (Lum, 2012: 15). Pada tahun 2012, aktivitas Balikatan fokus pada pelatihan penyerangan di Pulau Palawan yang merupakan wilayah paling dekat dengan wilayah sengketa di Kepulauan Spratly dan dekat dengan wilayah tambang minyak lepas pantai terbesar Filipina. Selain Balikatan, latihan militer lain dalam konteks ini ialah Cooperation Afloat Readiness and Training (CARAT) dan Amphibious Landing Exercise (PHIBLEX). Pada Juni 2011, latihan CARAT melibatkan 800 tentara AS dan 400 personil AFP di Laut Sulu. Dalam latihan tersebut disertakan pula dua kapal perusak AS, kapal penyelamatan, dan dua kapal patrol Filipina. Selanjutnya pada Oktober 2011, sekitar 2.000 anggota Angkatan Laut AS dan 1.000 Angkatan Laut AFP berlatih dalam kerangka latihan PHIBLEX. Selain mengadakan latihan militer bersama, AS juga mengadakan modernisasi militer di Filipina. Modernisasi tersebut berupa peningkatan kehadiran Angkatan Laut Filipina dan peningkatan kemampuan pasukannya melalui transfer salah satu kapal layar kualitas terbaik pada tahun yang sama (U.S. Department of State, 2012).

\section{Kerja Sama Pertahanan AS-Vietnam}

AS juga membina hubungan kerja sama pertahanan dengan Vietnam. Secara umum terdapat tiga tahap hubungan pertahanan antara kedua negara. Tahap pertama merupakan tahap inisiasi yang diawali dengan upaya menuju normalisasi hubungan kedua negara pada tahun 1995-1996 hingga tahun 2000 (Jordan, Stern, \& Lohman, 2012: 3). Hubungan antara AS dan Vietnam yang semakin kuat dan terus berkembang ditandai dengan normalisasi hubungan kedua negara dan kedatangan Menteri Pertahanan AS William Cohen ke Vietnam pada tahun 2000. Tahap kedua adalah masa antara tahun 2000 dan 2004 saat AS memperluas cakupan kerja sama dengan Vietnam. Periode ini juga dijabarkan sebagai periode 'pengenalan' (Jordan, Stern, \& Lohman, 2012: 4). Hubungan pertahanan antara AS dan Vietnam dikatakan sebagai hubungan yang berkembang secara perlahan, namun jauh lebih dekat daripada 15 tahun lalu. Tahap ketiga berjalan pada tahun 2005-2010, saat hubungan antara militermiliter mulai dibangun dengan memperluas kerja sama dan dialog. Sebelum memasuki kerja sama strategis, AS terlebih dahulu menggunakan kerja sama ekonomi sebagai penanda normalisasi hubungan antara kedua negara (Jordan, Stern, \& Lohman, 2012: 6). AS dan Vietnam melakukan hubungan ekonomi dengan menambahkan dimensi kerja sama strategis pada Desember 2006 dengan pernyataan resmi Gedung Putih mengenai penjualan senjata ke Vietnam:

'[the] furnishing of defense articles and defense services to Vietnam will strengthen the security of the United States and promote world peace' (Weatherbee, 2009: 45). 
Kerja sama militer formal pertama antara AS dan Vietnam dimulai pada 1 Agustus 2010 dengan ditandatanganinya Statement of Intent on Military Medical Cooperation di Hanoi. Pada bulan yang sama, AS dan Vietnam mengumumkan diadakannya Defense Policy Dialogue yang merupakan diskusi tingkat tinggi mengenai kerja sama militer. Diskusi tersebut berlanjut dengan kerja sama militer pertama AS-Vietnam berupa latihan bersama Angkatan Laut. Latihan bersama tersebut juga melibatkan masyarakat sipil untuk melatih pengaturan kerusakan, latihan pencarian, dan penyelamatan, serta pelatihan memasak di atas kapal USS John S. McCain yang berlabuh di Da Nang. Pelatihan serupa juga dilangsungkan pada Juli 2011 (Manyin, 2012: 20). Tahun 2010, galangan kapal Vietnam memperbaiki kapal-kapal U.S. Military Sealift Command. Latihan militer bersama juga diadakan pada 13 Juni 2011 di wilayah perairan sengketa. Latihan digelar dengan menggunakan peluru tajam menyusul konflik dengan Tiongkok terkait sengketa LTS. Sesi pertama latihan tersebut dilangsungkan selama sembilan jam di sekitar Hon Ong yang terletak sekitar $250 \mathrm{~km}$ dari Paracel atau hampir sekitar $1.000 \mathrm{~km}$ dari Spratly, diteruskan dengan sesi kedua pada malam hari selama lima jam. Latihan ini dikatakan oleh perwira Angkatan Laut Vietnam sebagai latihan rutin tahunan (Kompas, 2011: 10). AS juga melakukan peningkatan profesionalisme militer Vietnam dengan mengadakan kegiatan peacekeeping, keamanan lingkungan, serta kegiatan peningkatan tanggap bencana (Thayer, 2010).

Keterlibatan dan aktivitas-aktivitas (terutama militer) AS di kawasan LTS di atas memperlihatkan keseriusan AS untuk memperbesar kehadirannya di wilayah Asia-Pasifik. Dalam konteks sengketa di LTS, secara langsung maupun tidak langsung AS akan memberikan pengaruh bagi sengketa, terutama dalam hubungan AS dengan sekutunya dan Tiongkok. Penulis memahami bahwa kebijakan AS untuk terlibat dalam sengketa berkenaan erat dengan kepentingan-kepentingannya di wilayah sengketa, terutama dalam kerja samanya dengan Filipina dan Vietnam. Inilah yang akan dibahas pada bagian selanjutnya mengenai analisis kepentingan AS dalam sengketa LTS.

\section{Kepentingan dan Keamanan Nasional Amerika Serikat dalam Sengketa LTS}

Seperti yang telah dipaparkan penulis, selama ini AS mengutarakan kebijakan 'high-profile intervention' di Asia Pasifik dengan alasan yang jelas, antara lain keinginan untuk kebebasan bernavigasi di wilayah LTS, mendorong penyelesaian sengketa secara damai, mengharapkan bahwa sengketa tidak mempengaruhi perdamaian dan kestabilan kawasan, serta meminta setiap negara yang bersengketa menghargai prinsip-prinsip internasional. Kepentingan AS tersebut dapat dikaitkan dengan kerangka besar untuk mengimbangi peningkatan pengaruh dan kekuatan militer Tiongkok.

\section{Menjaga Kepemimpinan Global}

Menjaga kepemimpinan global menjadi kepentingan utama politik luar negeri AS. Hal ini terlihat dalam kata pengantar yang disampaikan Obama pada Pedoman Pertahanan AS:

'I am determined that we meet the challenges of this moment responsibly and that we emerge even stronger in a manner that preserves American global leadership, maintains our military superiority and keeps faith with our troops' (U.S. Department of Defense, 2012: iii).

Dalam memenuhi tuntutan untuk menjaga pengaruh dan kekuatannya, AS perlu hadir dan menunjukkan kemampuannya dalam setiap kesempatan penting pada tingkat internasional. Sengketa LTS yang menjadi satu perhatian internasional merupakan ajang penting bagi AS untuk menunjukkan kemampuan sekaligus menyangkal prediksi mengenai melemahnya pengaruh AS. Menurut Richard Hass, tidak ada negara atau kelompok negara yang akan dapat berada dalam posisi untuk mengimbangi kekuatan ekonomi, militer, dan budaya Amerika di masa mendatang. Meskipun demikian, AS tidak akan dapat mewujudkan ambisi maupun kepentingannya tanpa dukungan dari pihak lain (Haass, 2011).

AS membutuhkan power untuk menjaga keunggulan dan keamanan nasionalnya. Power merupakan hal utama yang mendorong hubungan internasional, baik sebagai tujuan atau sebagai sumber untuk meraih keamanan nasional. Kebutuhan AS untuk meningkatkan pengaruh di kawasan Asia-Pasifik berkaitan erat dengan kebangkitan 
Tiongkok. Berdasarkan perspektif realis, kebangkitan Tiongkok akan menimbulkan konflik antara kekuatankekuatan besar untuk melakukan rekonstruksi pengaturan kekuatan di kawasan. Dengan demikian, kawasan AsiaPasifik akan menjadi tempat kompetisi berbagai kekuatan besar dunia, seperti AS dan Tiongkok, untuk menciptakan struktur baru dalam mencapai kesetimbangan. Kebangkitan suatu negara maupun aliansi dengan kemampuan yang kuat akan menjadi ancaman yang akan mendominasi keseluruhan sistem dan oleh karenanya harus dilawan dengan kekuatan negara-negara untuk menjaga keamanan masing-masing (Odgaard, 2007: 15). Kebutuhan Asia untuk menciptakan balance of power akan melibatkan kekuatankekuatan besar di kawasan tersebut, seperti Tiongkok, Jepang, India, dan juga AS. Meskipun demikian, kekuatankekuatan besar tersebut diyakini memiliki satu tujuan, yaitu untuk mencegah terbentuknya satu kekuatan tunggal yang dominan (Minh, 2012).

Pedoman Pertahanan AS menyebutkan bahwa kemunculan Tiongkok sebagai kekuatan regional berpotensi mempengaruhi perekonomian dan keamanan AS dalam berbagai cara. Pedoman tersebut juga menyebutkan bahwa AS akan terus melakukan investasi penting untuk memastikan agar akses regional dan kemampuan untuk beroperasi secara bebas serta penegakan hukum internasional tetap terjaga (U.S. Department of Defense, 2012: 2). Pada salah satu misi utama AS yang termuat dalam dokumen pedoman strategis tersebut, terdapat poin 'project power despite anti-access/area denial challenges'. Pada poin tersebut, secara jelas AS menyatakan bahwa 'states such as China and Iran will continue to pursue asymmetric means to counter our power projection capabilities' (U.S. Department of Defense, 2012: 4). Hal ini juga terlihat dalam pernyataan Hillary Clinton di National Defense University, Washington:

'This is about the United States of America... We are reasserting our presence in the Pacific. We are a Pacific power. That means all elements of our national security team have to be present, and we can't be abruptly pulling back or pulling out when we know we face some long-term challenges about how we're going [to] cope with what the rise of China means.' (U.S. Departement of State, 2011).
Terlihat dari pernyataan tersebut bahwa AS memang menjadikan kehadiran Tiongkok sebagai satu ancaman bagi keamanannya dan AS merasa perlu untuk menjaga kepemimpinanya di kawasan Asia-Pasifik.

\section{Menjaga Perdamaian dan Kestabilan Kawasan}

Sistem internasional yang anarkis tidak menawarkan perlindungan, namun setiap negara harus memenuhi kemampuan relatifnya secara individual. Ironisnya, berbagai upaya yang dilakukan oleh negara-negara untuk melindungi diri sendiri menghasilkan dinamika yang mengancam keamanan dunia. Dinamika tersebut merupakan dilema keamanan yang dapat dipahami sebagai situasi di mana perang dan perlombaan senjata muncul antara dua aktor atau lebih, sekalipun pihak yang terlibat tidak menginginkan fenomena tersebut terjadi. Dilema keamanan timbul karena satu negara melihat tindakan dari negara lain sebagai tindakan agresif. Dengan istilah yang lebih abstrak, keamanan dari satu negara menjadi bentuk ketidakamanan bagi negara lainnya (Odgaard, 2007: 14). Melalui pandangan realis, kompetisi antarnegara menjadi suatu hal yang pantas dan jamak terjadi. Preposisi yang kemudian ditawarkan ialah dibutuhkannya suatu perimbangan kekuatan antara negara-negara untuk mencapai perdamaian.

Kompetisi yang dilakukan oleh negara-negara yang bersengketa di LTS berlangsung tidak seimbang, dengan pemahaman bahwa Tiongkok memiliki kemampuan militer dan ekonomi yang dominan. Distribusi kekuatan yang tidak seimbang menyebabkan tindakan intimidatif Tiongkok berupa tekanan militer dan ekonomi yang mencolok akibat ketimpangan kekuatan antara negaranegara pengklaim. Dalam konteks sengketa LTS, kerja sama militer antara AS dengan Filipina dan Vietnam memberikan kesempatan bagi kedua negara tersebut untuk bersaing secara lebih seimbang dengan Tiongkok. AS yang merupakan kekuatan utama berfungsi pula sebagai penyeimbang dan kekuatan pembanding Tiongkok. Dalam sengketa LTS, salah satu prioritas Amerika Serikat adalah untuk menjaga perdamaian dan kestabilan kawasan melalui penciptaan kesetimbangan kekuatan.

Menurut Hedley Bull, kekuatan utama akan memainkan peran dalam mendukung tatanan internasional 
dengan mencari kebijakan yang dapat diterapkan. Kebijakan tersebut akan bertujuan untuk menjaga kesetimbangan kekuatan secara umum, mencegah atau mengendalikan krisis dengan mencari batasan untuk menahan terjadinya perang antara satu negara dengan lainnya. Kekuatan utama juga memanfaatkan keunggulannya dengan melakukan eksploitasi melalui tindakan bersama untuk mempromosikan kebijakan kolektif menggunakan sistem internasional. Eksploitasi yang dilakukan oleh kekuatan utama tersebut bertujuan untuk mengatur hubungan yang saling menguntungkan untuk mencegah terjadinya konflik maupun perang di antara negara-negara (Bull, 2002: 194-222).

Keinginan AS untuk menjaga kestabilan dan keamanan kawasan diperlihatkan dengan berbagai upaya dalam membantu penyelesaian sengketa LTS. Dalam ketiadaan konsensus atau institusi yang kuat untuk menyelesaikan konflik di antara kekuatan-kekuatan besar, sebuah strategi kesetimbangan kekuatan menjadi kebijakan yang paling baik untuk diterapkan (Wiarda, 2011: 104). AS terbilang aktif untuk terlibat dalam isu kawasan dengan mendukung tindakan ASEAN dalam penyelesaian sengketa LTS dengan membangun konsensus dalam pembuatan prinsip dasar untuk mengatur dan mencegah eskalasi sengketa. AS mendorong ASEAN untuk membuat kemajuan berarti dalam rangka penyelesaian kode etik berperilaku (code of conduct) untuk menciptakan peraturan dan prosedur yang jelas dalam menyelesaikan sengketa secara damai. Pengelolaan tata internasional melalui diplomasi merupakan arena kekuatan politik, dan melalui hal tersebut negara kekuatan utama memperlihatkan keunggulannya dengan meletakkan sebagian proporsi kekuatannya dalam kegiatankegiatan diplomasi (Odgaard, 2007: 6).

\section{Mengamankan Jalur Pelayaran}

Pada dasarnya, UNCLOS telah memberikan jaminan bagi semua negara untuk menggunakan kebebasan navigasi di laut, namun keamanan navigasi akan bergantung pada implementasi hukum internasional oleh negara-negara di sekitar wilayah pantai (Wu \& Zou, 2009: 6). Dalam sengketa LTS, belum terdapat kesepakatan dan implementasi hukum internasional dari negara-negara bersengketa untuk bekerja sama mengelola wilayah sengketa, termasuk dalam aktivitas eksplorasi dan eksploitasi sumber daya.

Oleh karena itu, dapat dipahami mengapa AS bersikeras untuk menegakkan hukum internasional dan menerapkan UNCLOS dalam sengketa LTS. Ironisnya, AS belum melakukan ratifikasi atas UNCLOS. Amerika Serikat dan beberapa negara lain yang belum meratifikasi UNCLOS masih menggunakan batas perhitungan tiga mil sebagai perpanjangan dari batas yurisdiksi negara dan juga meyakini bahwa kapal militer dan perdagangannya memiliki hak untuk melalui perairan negara lain tanpa perlu menyampaikan pemberitahuan lebih dulu (Wu \& Zou, 2009: 104). AS selalu menyatakan ketegasan bahwa penerapan hukum internasional, terutama UNCLOS, harus menjadi landasan berpikir dan bertindak oleh negara-negara bersengketa di LTS. Oleh sebab itu, dapat dipahami kemudian mengapa Amerika Serikat, melalui Hillary Clinton, telah berupaya untuk mendesak Senat agar mendukung ratifikasi UNCLOS. Pembahasan dan sesi hearing di Senat yang dihadiri oleh Clinton, Menteri Pertahanan Leon Panetta, dan Kepala Staf Gabungan Jenderal Martin Dempsey mengenai ratifikasi UNCLOS telah dilakukan pada Mei 2012.

Upaya AS untuk menjaga keamanan jalur pelayaran di wilayah perairan LTS berkaitan dengan kepentingannya untuk menjalankan kebutuhan militer dan juga kepentingan untuk menjaga keamanan Sea Lines of Communications (SLOCs) di LTS. AS memegang prinsip bahwa armadanya harus dapat secara bebas berlalu lintas tanpa halangan di semua penjuru dunia (Wibisono, 2012: 6). Dengan pentingnya posisi LTS untuk menjaga kelancaran arus distribusi perdagangan di dunia, selain untuk menjaga keamanan mobilitas militernya di jalur LTS, AS juga berkepentingan untuk menjaga kepentingan ekonominya di wilayah tersebut. Nilai perdagangan yang melewati jalur LTS mencapai $\$ 5,3$ triliun, dengan $\$ 1,2$ triliun di antaranya merupakan nilai perdagangan negara adidaya tersebut (Kompas, 2011: 6).

Keamanan dan keselamatan kegiatan maritim perlu diberi jaminan terhadap pembajakan laut, aksi terorisme, serta perdagangan senjata, obat-obatan, dan manusia secara ilegal. Keamanan dan keselamatan navigasi juga berkembang menjadi kebutuhan untuk pertolongan navigasi, 
survei hidrografik, serta kegiatan pencarian dan penyelamatan yang dibutuhkan untuk mengamankan dan menyelamatkan kapal-kapal yang melalui LTS (Bateman \& Emmers, 2009: 2). AS sebagai negara kekuatan dunia memiliki berbagai alasan untuk meningkatkan kehadirannya di perairan Asia Tenggara demi mengamankan mobilitas strategisnya dari Samudera Hindia dan Pasifik. Di antara alasan itu adalah adanya ancaman terhadap distribusi perdagangan seperti pembajakan dan terorisme (Tow, 2009: 252). Oleh karena itu, kerja sama Amerika Serikat dengan negara-negara yang bersengketa di LTS, seperti Filipina dan Vietnam, meliputi juga latihan untuk menangani berbagai masalah evakuasi dan penyelamatan serta berbagai tindakan non-tradisional lainnya, seperti penanganan masalah hak asasi manusia dan peningkatan demokrasi di kedua negara.

Selain jalur pelayaran di LTS, ambisi Tiongkok dalam proyek 'Belt and Road Initiative' (BRI) merupakan faktor penting keterlibatan AS di wilayah LTS. ${ }^{3}$ BRI merupakan strategi Tiongkok untuk mempromosikan integrasi ekonomi dengan pembangunan infrastruktur transportasi dan energi melalui jalur darat dan laut sampai kawasan Afrika dan Eropa Barat. Menurut persepsi AS, Tiongkok berusaha menggunakan BRI untuk mengekspor surplus kapasitas dalam negeri mereka, seperti material-material konstruksi, jasa rancang-bangun, serta surplus pekerja (Chance \& Mafinezam, 2016: 10). Meskipun Tiongkok selalu menekankan kepentingan ekonomi, persepsi AS terhadap BRI meliputi kekhawatiran mengenai kepentingan militer dan keamanan. BRI dipandang sebagai bagian dari tujuan Tiongkok untuk mencapai posisi hegemon dengan meletakkan dasar-dasar bagi tatanan Sino-sentris (Chance \& Mafinezam, 2016: 9). Dengan adanya pembangunan pelabuhan di Kolkata (India), Colombo (Sri Lanka), Gwadar (Pakistan), dan Mombasa (Kenya) untuk memfasilitasi jalur pelayaran BRI, AS khawatir bahwa pembangunan pelabuhan-pelabuhan tersebut akan diikuti dengan kehadiran angkatan laut Tiongkok dengan alasan melindungi dan menjaga kapal-kapal Tiongkok. Oleh karena itu, kehadiran dan keterlibatan AS di sengketa LTS tidak lepas dari pendekatan yang kompetitif terhadap pengaruh dan potensi kehadiran militer Tiongkok di perairan Asia Pasifik.
KERJA SAMA AMERIKA SERIKAT DAN STATUS QUO SENGKETA LTS

Mengapa AS bekerja sama dengan Filipina dan Vietnam? Di sini perimbangan kekuatan dan keamanan nasional menjadi konsep-konsep yang akan penulis gunakan untuk menelaah strategi AS tersebut.

Michael Lind (2006: 40) menyebutkan bahwa 'fear has guided American security strategy since the end of Cold War'. Penulis berasumsi, kekhawatiran AS akan hilangnya hegemoni akibat kebangkitan Tiongkok merupakan pendorong AS untuk melakukan kerja sama dengan Filipina dan Vietnam. Kerja sama dengan kedua negara tersebut juga dipahami sebagai strategi AS untuk mendekatkan diri pada wilayah 'pivot' atau untuk melakukan 'rebalance' di Asia. Namun demikian, AS membutuhkan pendekatan baru untuk tetap menjadi negara yang terdepan di seluruh dunia. Seperti ditunjukkan dalam tabel di bawah ini, bantuan keamanan AS kepada negara-negara Asia Tenggara cenderung menurun. Hal ini merupakan pengaruh dari krisis ekonomi yang melanda AS.

TABEL 1. Bantuan Keamanan AS kepada Negaranegara di Asia Tenggara (dalam juta dollar AS)

\begin{tabular}{lll}
\hline NEGARA & $\mathbf{2 0 1 0}$ & $\mathbf{2 0 1 5}$ \\
\hline Myanmar & 0 & 0,5 \\
Thailand & 15,9 & 3,2 \\
Kamboja & 7 & 6,2 \\
Indonesia & 66,5 & 32,1 \\
Singapura & 0,7 & 0,2 \\
Brunei Darussalam & 0,1 & 0 \\
Laos & 5,7 & 13,6 \\
Vietnam & 6,8 & 17,7 \\
Filipina & 73,9 & 67,4 \\
Malaysia & 5,5 & 2,3 \\
\hline
\end{tabular}

Sumber: Council on Foreign Relations, 2015.

Sebagaimana ditunjukkan dalam tabel, bantuan AS kepada Vietnam mengalami peningkatan, sementara bantuan AS kepada Filipina merupakan yang terbesar di antara negara lainnya. Dengan kesulitan biaya untuk memenuhi dan menyokong kebutuhan pertahanan serta operasi militer di luar negeri akibat krisis ekonomi, AS melakukan kerja sama untuk menggunakan fasilitasfasilitas yang telah tersedia di negara lain. Selain meringankan biaya dan meningkatkan aliansi dengan 
negara-negara strategis, AS juga dapat memperkuat posisinya dalam sengketa LTS. Selain karena kendala pembiayaan, pendekatan AS kepada negara-negara di sekitar wilayah sengketa berkaitan pula dengan strategi 'returning to Asia-Pacific' yang dipertegas oleh Clinton dengan pernyataan 'back and stay to Asia-Pacific' (Liming, 2012). Dengan anggapan bahwa AS merupakan residence power atau termasuk sebagai satu kekuatan yang ada di Asia, AS merasa harus terlibat dalam sengketa LTS.

AS sendiri juga memiliki nilai perdagangan yang cukup besar dengan Tiongkok. Karakter relasi ekonomi dan perdagangan AS-Tiongkok adalah saling ketergantungan (Ministry of Commerce of the People's Republic of China, 2017: 12). Seperti yang ditunjukkan dalam Tabel 2, nilai perdagangan kedua negara yang sangat besar memperlihatkan adanya hubungan ekonomi yang juga besar di antara kedua negara. Pada tahun 2011 misalnya, nilai perdagangan antara kedua negara yaitu $\$ 503,2$ miliar (The US-China Business Council, 2011).

\section{TABEL 2. Nilai Perdagangan Barang AS terhadap} Tiongkok (dalam juta dollar AS)

\begin{tabular}{llll}
\hline TAHUN & EKSPOR & IMPOR & KESEIMBANGAN \\
\hline 2008 & 69.732 & 337.772 & -268.039 \\
2009 & 69.496 & 296.373 & -226.887 \\
2010 & 91.911 & 364.952 & -273.041 \\
2011 & 104.121 & 399.371 & -295.249 \\
2012 & 110.516 & 425.619 & -315.102 \\
2013 & 121.746 & 440.430 & -318.683 \\
2014 & 123.657 & 468.474 & -344.817 \\
2015 & 115.932 & 483.188 & -367.256 \\
2016 & 115.602 & 462.618 & -347.016 \\
$2017 *$ & 69.284 & 273.511 & -204.227 \\
\hline
\end{tabular}

*) Sampai bulan Juli $2017 \backslash$ Sumber: U.S. Census Bureau, 2017.

Seperti ditunjukkan tabel di atas, dalam perdagangan barang, AS mengalami defisit perdagangan dengan Tiongkok. ${ }^{4}$ Meskipun AS mengalami defisit perdagangan barang terhadap Tiongkok, namun pelaku bisnis dan konsumen AS mendapatkan beberapa keuntungan dari relasi perdagangan tersebut (Holmes, 2017). Pertama, AS masih mengalami surplus dalam hal perdagangan jasa, seperti yang ditunjukkan dalam Gambar 1. Secara total, Tiongkok membeli barang dan jasa dari AS sebesar $\$ 165$ miliar pada tahun 2015. Pada tahun 2016, Tiongkok merupakan pasar luar negeri terbesar kedua AS dengan penjualan senilai $\$ 400$ miliar (The US-China Business Council, 2016). ${ }^{5}$ Kedua, ekspor dan investasi dengan Tiongkok telah membuka 2,6 juta pekerjaan dan menyumbang sekitar \$216 miliar GDP AS pada tahun 2015. Meskipun kritik muncul karena perusahaan AS di Tiongkok memproduksi barang di Tiongkok hanya untuk dijual kembali ke AS, namun data pada tahun 2013 menunjukkan bahwa hanya $6 \%$ produk yang dikirim kembali ke AS dan sekitar 80\% dijual di pasar dalam negeri Tiongkok. Ketiga, barang-barang impor dari Tiongkok membuat pelaku bisnis AS membayar harga lebih rendah untuk barang-barang yang dibeli konsumen. Tentu masingmasing negara yang bersengketa tidak ingin mengorbankan kepentingan ekonominya dengan mengedepankan tindakan reaktifnya terhadap sengketa, dan negara-negara tersebut juga tidak dapat mengabaikan keberadaan AS di kawasan yang juga menjadi salah satu investor asing utama mereka. Hubungan ekonomi yang terjalin antara negaranegara bersengketa di LTS dan juga AS membuat kompleksitas sengketa semakin tinggi. Hal ini membuat kemungkinan terjadinya perang terbuka di LTS semakin kecil.

Oleh karena itu, keterlibatan AS dalam sengketa LTS cukup dengan menjadi penyeimbang kekuatan di kawasan dan sebatas sampai pada situasi deterrence. Dalam teori deterrence klasik, perimbangan kekuatan merupakan hal yang sangat esensial untuk menciptakan stabilitas. Perdamaian diharapkan muncul dari distribusi kekuatan yang setara di antara aktor (Kumar, 2007: 241). Meski bantuan keamanan AS cenderung menurun seperti yang ditunjukkan dalam Tabel 1, namun anggaran pertahanan negara-negara Asia Tenggara cenderung meningkat (SIPRI, 2015). Dari tahun 2014 sampai 2015, anggaran pertahanan Filipina naik sebesar 25,5\%, sementara Vietnam dan Malaysia masing-masing 7,6\% dan 7,7\%. Hal ini tidak lepas dari peran AS yang memasok persenjataan kepada negaranegara yang bersengketa. Kebutuhan persenjataan dan pertahanan bagi negara-negara yang bersengketa di LTS merupakan hal yang mutlak untuk dipenuhi. Hal tersebut berkaitan dengan upaya negara-negara tersebut untuk melakukan deterrence. Kekhawatiran negara-negara bersengketa terhadap peningkatan aktivitas militer negaranegara lain, terutama aktivitas militer Tiongkok yang masif, 
menyebabkan peluang industri senjata AS terbuka lebih lebar. Penjualan senjata ke wilayah Asia-Pasifik menjadi satu target besar bagi negara-negara produsen senjata, termasuk AS.

Dalam konteks sengketa LTS, AS juga memiliki kepentingan ekonomi dalam bentuk penjualan senjata. Volume penjualan senjata AS ke seluruh dunia mencapai rekor tertingginya, yaitu sebesar $\$ 66,3$ miliar pada tahun 2011, atau tiga kali lipat dari penjualan pada tahun sebelumnya sebesar $\$ 21,4$ miliar. Sedangkan total penjualan senjata dunia pada tahun yang sama ialah sebesar $\$ 85,3$ miliar, naik dari tahun sebelumnya senilai $\$ 44,5$ miliar. Rekor penjualan senjata AS tersebut merupakan yang tertinggi di dunia sejak tahun 2004. Dari data ini, dapat dikatakan bahwa AS bertanggung jawab terhadap tiga perempat penjualan senjata secara global (Grimmett \& Kerr, 2012: 1). Penjualan senjata di wilayah Asia-Pasifik juga mengalami peningkatan menjadi total $\$ 13,7$ miliar pada tahun 2012, atau meningkat sekitar 5,4\% dari tahun sebelumnya (Wolf, 2013). Untuk penjualan senjata di Asia pada tahun 20082011, AS menempati peringkat pertama dengan 30,1\%
( $\$ 18,1$ miliar) dan Rusia di tempat kedua dengan penjualan sebesar 27\% (\$16,3 miliar) (Grimmett \& Kerr, 2012: 15). Sedangkan untuk penjualan senjata ke negara-negara di Asia Tenggara yang berada di sekitar wilayah sengketa LTS, AS juga melakukan perdagangan dalam persentase yang cukup besar (lihat Tabel 3). Kontraktor-kontraktor seperti Lockheed Martin, Boeing, Northrop Grumman, dan Raytheon menjadi perusahaan-perusahaan yang membantu Pentagon dalam memproduksi persenjataan, terutama untuk mengimbangi pengetatan anggaran yang dilakukan oleh pemerintah.

Data di atas menunjukkan bahwa AS memiliki persentase penjualan persenjataan yang cukup besar bagi negaranegara di Asia Tenggara. ${ }^{6}$ Sesuai dengan teori deterrence, perimbangan kekuatan dan distribusi kekuatan yang merata di antara aktor di kawasan merupakan kondisi yang ideal untuk menjaga strategi keseimbangan dan status quo (Kumar, 2007: 241). Status quo akan terpelihara karena tidak ada negara yang memiliki kapabilitas untuk mengubah situasi secara drastis karena kekuatan aktor yang merata. Begitu juga sebaliknya, jika sistem deterrence tidak stabil,

\section{GAMBAR 1. Perdagangan Jasa AS-Tiongkok, 2006-2016 (dalam juta dollar AS)}

\section{$\$ 60$}

$\$ 50$

$\$ 40$

$\$ 30$

$\$ 20$

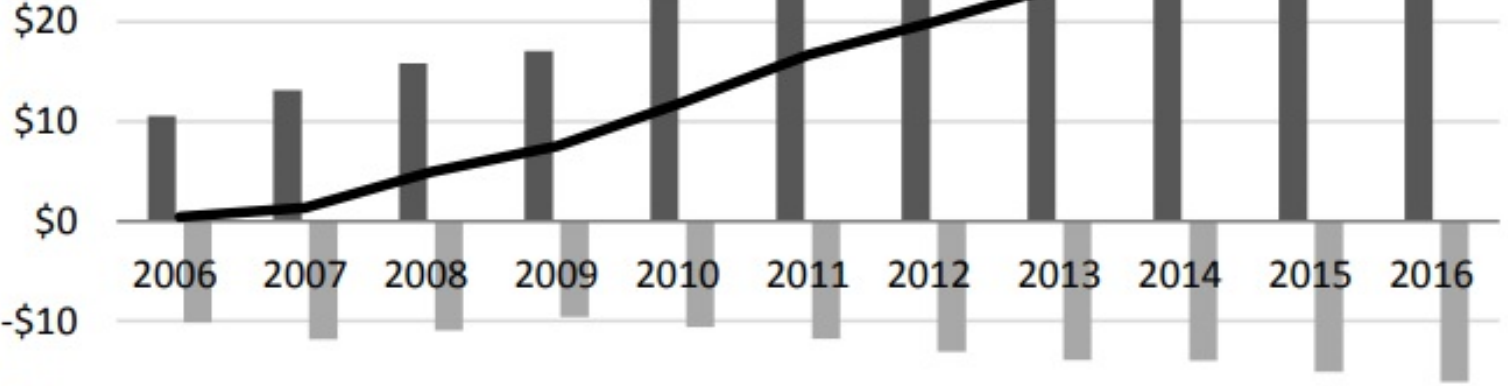

$-\$ 20$

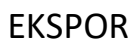

IMPOR

KESEIMBANGAN 
krisis atau perang sangat mungkin terjadi. Dengan keterlibatan AS sebagai penyeimbang kekuatan di kawasan, kemungkinan akan terjadinya perang atau konflik terbuka di LTS menjadi berkurang.

TABEL 3. Nilai Penjualan Persenjataan Amerika Serikat ke Negara Mitra Dagang Utama di Asia Tenggara (dalam dollar AS)

\begin{tabular}{llll}
\hline NO & \multirow{2}{*}{ NEGARA } & $\begin{array}{l}\text { PENJUALAN SENJATA } \\
\text { AS }(2000-2006)\end{array}$ & $\begin{array}{l}\text { PERSENTASE DARI TOTAL } \\
\text { PEMBELIAN SENJATA }\end{array}$ \\
\hline 1. & Filipina & 59 juta & $70,4 \%$ \\
2. & Vietnam & Belum ada data & Belum ada data \\
3. & Thailand & 406 juta & $55,2 \%$ \\
4. & Singapura & 1,67 miliar & $79,6 \%$ \\
5. & Indonesia & 40 juta & $5 \%$ \\
6. & Malaysia & 59 juta & $5,44 \%$ \\
\hline
\end{tabular}

Sumber: CSIS, 2009.

\section{KESIMPULAN}

Kehadiran militer AS di kawasan dalam sengketa LTS memiliki kemungkinan berlawanan dengan upayanya menyelesaikan dan mengurangi resiko sengketa karena meningkatkan ketegangan pihak-pihak yang bertikai, terutama antara Filipina dan Tiongkok. Kerja sama AS dengan Filipina dan Vietnam juga menjadi hal penting untuk diteliti lebih jauh. Hal tersebut berkaitan dengan strategi AS dalam merespon sengketa LTS dan dasar kepentingan AS dalam pemenuhan kepentingannya di Filipina dan Vietnam yang terlibat langsung dalam sengketa. Kerja sama yang dilakukan AS di kawasan dapat diartikan sebagai bentuk dukungan terhadap negara-negara tertentu dalam sengketa dan cenderung menyudutkan Tiongkok.

Meski demikian, kehadiran dan keterlibatan AS yang bukan bagian dari pihak yang melakukan klaim wilayah dalam sengketa LTS merupakan bagian dari strategi perimbangan kekuatan di kawasan. Sebagai kekuatan penyeimbang, AS menerapkan pendekatan baru, yaitu melakukan kerja sama militer dengan Filipina dan Vietnam, memberikan bantuan asistensi keamanan (meskipun anggaran cenderung menurun), serta melanjutkan penjualan senjata ke negara-negara dagang utama di Asia Tenggara. Pendekatan tersebut dilakukan karena AS tengah menghadapi krisis ekonomi global. Namun, perimbangan kekuatan AS terhadap Tiongkok tidak berujung pada krisis atau konflik terbuka di lapangan karena AS memiliki relasi perdagangan yang saling menguntungkan dengan Tiongkok. AS juga melihat kawasan LTS yang damai dan stabil merupakan prioritas penting untuk keamanan nasional AS. Strategi tersebut menghasilkan situasi deterrence di kawasan yang memelihara status quo dalam sengketa LTS.

\section{CATATAN BELAKANG:}

Menurut Richmond Llyod (2009: 126), terdapat tiga tahap kehadiran negara adidaya tersebut di kawasan. Fase pertama merupakan periode awal kehadiran AS, yaitu masa awal adventurisme dan ekspansionisme di tahun-tahun 1776-1946. Ekspansi AS ditunjukkan dengan pendudukan di Filipina pada masa imperialisme Barat, diikuti dengan berakhirnya masa kolonialisme melalui era self determination yang juga diperkenalkan oleh AS pada masa perang dunia dan dekolonialisasi. Fase kedua ialah periode anti-komunisme dan ambiguitas (1946-1989), yang mana kebijakan pertahanan pada masa Perang Dingin ditandai dengan pertentangan dalam dukungan AS terhadap rezim otoriter di satu sisi dan pernyataannya mengenai nilai-nilai liberal-demokratis untuk melawan komunisme di sisi yang lain. Asia Tenggara menjadi garis depan yang penting bagi AS. Fase terakhir merupakan periode pasca Perang Dingin (1989-2009). AS pada masa ini meletakkan prioritas dalam melakukan strategi counterterrorism dengan ancaman dari 'ekstrimis' Islam pasca peristiwa 11 September 2001. Kawasan Asia Tenggara sebagai salah satu rumah bagi kebanyakan umat Islam di dunia sekali lagi menjadi satu kalkulasi pertimbangan strategi militer AS.

2 Meskipun AS berjanji untuk meningkatkan kerja sama militer dan bantuan terhadap militer Filipina, namun AS tidak berencana untuk membangun pangkalan militer secara permanen (Lum, 2012: 2). Sebelumnya, AS telah memiliki pangkalan militer di Filipina, yaitu Pangkalan Angkatan Laut Subic di Zambales dan Pangkalan Angkatan Udara Clark di Pampanga. Kedua pangkalan militer tersebut dulunya merupakan pangkalan terbesar AS di luar AS, yang pada 30 September 1992 ditutup karena Senat Filipina menolak perpanjangan sewa pangkalan militer (Bayoneto, 2011: 111). Meskipun demikian, mulai Juni 2012, tentara AS diperbolehkan untuk memakai fasilitas militer di kedua pangkalan tersebut dengan izin dari pemerintah Filipina (Laudem, 2012).

3 'Belt and Road Initiative' merupakan istilah resmi pemerintah Tiongkok untuk menyebut 'One Belt, One Road' (Forbes, 2017). Tiongkok menegaskan hal tersebut untuk mengurangi misinterpretasi karena pada kenyataannya, rute yang diinisiasi Tiongkok tidak tunggal, melainkan lima rute darat dan laut. Inisiatif ini berawal dari pidato Presiden Xi Jinping. Tiongkok pertama kali mengenalkan visi 'Silk Road Economic Belt' kepada masyarakat internasional dalam pidato Presiden Xi Jinping pada bulan September 2013 di Universitas Nazarbayev, Astana, 
Kazakhstan. Setelah itu, Presiden Xi Jinping mengenalkan visi 'the Maritime Silk Road' di depan parlemen Indonesia pada bulan Oktober 2013 (Chance \& Mafinezam, 2016: 3).

4 Antara tahun 2008 sampai 2016, defisit perdagangan AS terhadap Tiongkok setara dengan 30-50\% dari total defisit perdagangan AS (US-China Economic and Security Review Commission, 2017: 17).

5 Pasar luar negeri terbesar bagi perusahaan AS adalah Kanada, yaitu senilai $\$ 800$ miliar.

6 Dalam Tabel 3, nilai penjualan persenjataan AS kepada Vietnam belum dapat didata karena hubungan militer-militer yang dilakukan antara kedua negara baru diinisiasi sekitar tahun 2005-2010. Kegiatan asistensi militer yang dilakukan AS saat ini mengalami perbaikan dengan adanya perdagangan persenjataan ke Vietnam berupa senjata tidak mematikan (nonlethal), serta penjualan peralatan pertahanan lainnya. Berdasarkan laporan anggaran tahunan Kementerian Luar Negeri AS pada tahun fiskal 2007-2010, kementerian telah mengeluarkan izin senilai sekitar $\$ 98,5$ juta untuk pengadaan peralatan pertahanan dan $\$ 3,7$ juta untuk jasa pertahanan ke Vietnam (Manyin, 2012: 21).

\section{REFERENSI}

\section{BUKU, JURNAL, DAN DOKUMENTASI RESMI}

Abinales, P. (2004). American Military Presence in the Southern Philippines: A Comparative Historical Overview. East-West Center Working Papers, No. 7, 1-20.

Ayoob, M. (1999). From Regional System to Regional Society: Exploring Key Variables in the Construction of Regional Order. Australian Journal of International Affairs, 53 (3), 247-260.

Bayoneto, M.V. (2011). The Former U.S. Bases in the Philippines: An Argument for the Application of U.S. Environmental Standards to Overseas Military Bases. Fordham Environmental Law Review, $6(1), 111-155$.

Bull, H. (2002). The Anarchical Society: A Study of Order in World Politics, $3^{\text {rd }}$ edn. New York: Palgrave.

Buzan, B. \& Wæver, O. (2006). Regions and Powers: The Structure of International Security, $4^{\text {th }}$ edn. Cambridge: Cambridge University Press.

Chance, A. \& Mafinezam, A. (2016). American Perspectives on the Belt and Road Initiative: Sources of Concern and Possibilities for Cooperation. Washington, DC: Institute for China-America Studies.

CSIS. (2009). U.S. Alliances and Emerging Partnerships in Southeast Asia: Out of the Shadows. A report of the CSIS Southeast Asia initiative. Washington, DC: CSIS.

Fravel, M. T. (2012). The US and China in Regional Security: Implications for Asia and Europe. Makalah dalam The $6^{\text {th }}$ Berlin Conference on Asian Security, 18-19 June, di Berlin, Jerman.

Grimmett, R. F. \& Kerr, P. K. (2012). Conventional Arms Transfer to Developing Nations, 2004-2011. Congressional Research Service Reports.

Haryanto, A., \& Bakhtiar, A. (2015). Sengketa Laut Tiongkok Selatan: Ancaman bagi Komunitas Keamanan ASEAN?. Jurnal Global \& Strategis, Th. 9, No. 2, 277-292.
Jordan, W., Stern, L. M. \& Lohman, W. (2012). U.S.-Vietnam Defense Relations: Investing in Strategic Alignment. Backgrounder, No. 2707, 1-13.

Kegley, C. W. \& Wittkopf, E. R. (2001). World Politics: Trend and Transformation, $8^{\text {th }}$ edn. New York: Bedford/St. Martin's.

Kumar, A. (2007). Theories of Deterrence and Nuclear Deterrence in the Subcontinent. Dalam E. Sridharan (Ed.), The India-Pakistan nuclear relationship: theories of deterrence and international relations, 239-265. New Delhi: Routledge.

Lind, M. (2006). The American Way of Strategy: U.S. Foreign Policy and The American Way of Life. New York: Oxford University Press.

Lloyd, R. M. (ed.). (2009). American Foreign Policy: Regional Perspectives. Proceedings of a Workshop sponsored by the William B. Ruger Chair of National Security Economics, 13-15 Mei.

Lum, T. (2012). The Republic of the Philippines and U.S. Interests. Congressional Research Service Report.

Manyin, M. E., et al. (2012). Pivot to the Pacific? The Obama Administration's 'Rebalancing' Toward Asia. Congressional Research Service Report.

Manyin, M. E. (2012). U.S.-Vietnam Relations in 2011: Current Issue and Implications for U.S. Policy. Congressional Research Service Report.

Minh, P. Q. (2012). The South China Sea Issue and Its Implications: Perspective from Vietnam. Risalah diskusi dalam The $6^{\text {th }}$ Berlin Conference on Asian Security tentang The U.S. and China in Regional Security: Implications for Asia and Europe,18-19 Juni, di Berlin.

Morgenthau, H. J. (1991). Politik Antar Bangsa, Edisi Ketiga. Jakarta: Yayasan Obor Indonesia.

Nye, J. S. (2005). Understanding International Conflict: An Introduction to Theory and History, $6^{\text {th }}$ edn. New York: Pearson Longman.

Odgaard, L. (2007). The Balance of Power in Asia-Pacific Security: US-China Policies on Regional Order. New York: Routledge.

Paul, T. V., Wirtz, J. J., \& Fortmann, M. (eds.). (2004). Balance of Power: Theory and Practice in the $21^{\text {st }}$ Century. Stanford: Standford University Press.

SIPRI, 2015. SIPRI Year Book 2015: Armaments, Disarmaments, and International Security. Stockholm International Peace Research Institute: Oxford University Press.

Tow, W. T. (ed.). (2009). Security Politics in the Asia-Pacific: A Regional-Global Nexus? New York: Cambridge University Press.

U.S. Department of Defense. (2012). Sustaining Global Leadership: Priorities for $21^{\text {st }}$ Century Defense.

U.S. Department of Defense. (2012). National Defense Budget Estimates for FY 2013.

Wiarda, H. J. (2011). American Foreign Policy in Regions of Conflict: A Global Perspective. New York: Palgrave MacMillan.

Wu, S. \& Zou, K. (eds.). (2009). Maritime Security in the South China Sea: Regional Implications and International Cooperation. Burlington: Ashgate.

\section{INTERNET}

BBC News. (2012, 10 Agustus). South China Sea Dispute. Diakses dari http://www.bbc.co.uk/news/world-asia-pacific-13748349. 
Castro, R. C. (2012). Future Challenges in the US-Philippines Alliance. Asia Pacific Bulletin, No. 168. Diakses dari http:// www.eastwestcenter.org/sites/default/files/private/apb168.pdf.

China Daily. (2011, 3 Agustus). US, Vietnam Agree 15t Formal Military Ties. Diakses dari http://www.chinadaily.com.cn/world/ 2011-08/03/content_13037452.htm.

Clinton, H. (2011). America's Pacific Century. Foreign Policy. Diakses dari http://www.foreignpolicy.com/articles/2011/10/11/ americas_pacific_century?page $=$ full.

Council on Foreign Relations. (2015). America's Pivot to Asia Actually Led to Drop in Security Assistance for Southeast Asi. Diakses dari http://www.huffingtonpost.com/council-onforeign-relations/pivot-asia-security_b_9830182.html.

Forbes. (2017, 1 Agustus). Beijing To The World: Don't Call The Belt And Road Initiative OBOR. Diakses dari https:// www.forbes.com/sites/wadeshepard/2017/08/01/beijing-to-theworld-please-stop-saying-obor/\#5026cd2417d4.

Greenert, J. (2011). Navy 2025: Forward Warfighters. Proceeding, 137 (12). Diakses dari http://www.usni.org/magazines/ proceedings/2011-12/navy-2025-forward-warfighters.

Haass, R. N. (2011). Foreign Policy in the Age of Primacy: An Overview. The Brookings Institution. Diakses dari http:// www.brookings.edu/research/articles/2000/09/fall-diplomacyhaass.

Holmes, J. R. (2013, 7 Maret). What to Make of China's Defense Spending Increase. The Diplomat. Diakses dari http:// thediplomat.com/the-naval-diplomat/2013/03/07/what-tomake-of-chinas-defense-spending- increase/.

Kate, D. T. (2011, 26 Mei). South China Sea Rush Risks Clashes as US Emboldens Vietnam on Claims. Bloomberg. Diakses dari http://www.bloomberg.com/news/2011-05-26/s-china-sea-oilrush-risks-clashes-as-u-s-emboldens-vietnam.html.

Liming, W. (2012, 29 Agustus). Commentary: It Is Unwise for US to Contain China. Xinhua. Diakses dari http:// news.xinhuanet.com/english/indepth/2012-08/29/ c_131815766.htm.

Thayer, C. A. (2010, 19 Agustus). Vietnam's Defensive Diplomacy. The Wall Street Journal. Diakses dari http://online.wsj.com/ article/ SB10001424052748703649004575438474083884494.html

The New York Times. (2012, 6 Januari). Text: Obama's Remarks on Military Spending. Diakses dari http://www.nytimes.com/ 2012/ 01/06/us/text-obamas-remarks-on- military-spending.html?ref$=u s \&$ $r=0$.

The US-China Business Council. (2016). Importance of China to the US Economy. Diakses dari https://www.uschina.org/tradefacts.

U.S. Census Bureau. (2017). Trade in Goods with China. Diakses dari https://www.census.gov/foreign-trade/balance/c5700.html.

US-China Economic and Security Review Commission. (2017). Annual Reports: US-China Economic and Trade Relations. Diakses dari https://insidecybersecurity.com/sites/ insidecybersecurity.com/files/documents/aug2017/ cs2017_0295.pdf.

U.S. Department of State. (2012). Remarks With Secretary of Defense Leon Panetta, Philippines Foreign Secretary Albert del Rosario, and Philippines Defense Secretary Voltaire Gazmin
After Their Meeting. Diakses dari http://www.state.gov/ secretary/rm/2012/04/ 188982.html.

(2011). A Conversation with Secretaries Hillary Clinton and Leon Panetta. Diakses dari http://www.state.gov/secretary/rm/ 2011/08/170611.htm.

(2010). Remarks at Press Availability. Diakses dari http:// www.state.gov/secretary/rm/2010/07/145095.html. (1995). U.S. Department of State Daily Press Briefing. Diakses dari http://dosfan.lib.uic.edu/ERC/briefing/daily_briefings/1995/ 9505/950510db.html.

VOA. (2011). Clinton on Manila Declaration. Diakses dari http:// editorials.voa.gov/content/clinton-on-manila-declaration134826743/1482849.html.

Weisgerber, M. (2012, 3 Juni). Pentagon Looks to Expand Military Relationship with Vietnam. Defense News. Diakses dari http:// www. defensenews.com/article/20120603/DEFREG02/ 306030002/Pentagon-Looks-Expand-Military-RelationshipVietnam.

Wolf, J. (2013, 1 Januari). Analysis: U.S Arms Sales to Asia Set to Boom on Pacific "Pivot". Reuters. Diakses dari http:// www.reuters.com/article/2013/01/01/us-usa-asia-arms-salesidUSBRE90005D20130101.

\section{SURAT KABAR}

Holmes, Frank, (2017). 'China Sets Stage To Replace U.S. As Global Trade Leader', Forbes, 31 Januari.

Wibisono, M. (2012). 'Sengketa Laut Cina Selatan', Kompas, 11 Desember. 